https://doi.org/10.52058/2708-7530-2021-3(9)-37-50

Войтенко Архип Борисович кандидат наук 3 державного управління, Заслужений юрист України, професор кафедри економічної теорії, інтелектуальної власності та публічного управління, Поліський національний університет, бульвар Старий, 7, м. Житомир, 10008, тел.: (067) 440-03-49, e-mail: public.znau@gmail.com, https://orcid.org/0000-0001-8661-2101

Ходаківський Свгеній Іванович доктор економічних наук, професор, Заслужений діяч науки і технічки України, професор кафедри економічної теорії, інтелектуальної власності та публічного управління, Поліський національний університет, бульвар Старий, 7, м. Житомир, 10008, тел.: (067) 440-03-49, e-mail: public.znau@gmail.com, https://orcid.org/0000-0001-8661-2101

Булуй Олексій Григорович кандидат економічних наук, доцент, доцент кафедри інноваційного підприємництва та інвестиційної діяльності, Поліський національний університет, бульвар Старий, 7, м. Житомир, 10008, тел.: (097) 21910-83, e-mail: obuluy@ukr.net, https://orcid.org/0000-0003-3368-4835

Плотнікова Марія Федорівна кандидат економічних наук, доцент, доцент кафедри інноваційного підприємництва та інвестиційної діяльності, Поліський національний університет, бульвар Старий, 7, м. Житомир, 10008, тел.: (067) 44003-49, e-mail: mfplotnikova@gmail.com, https://orcid.org/0000-0003-2852-3009

\title{
ПСИХОЛОГІЧНІ ЗАСАДИ УПРАВЛІННЯ ІНФОРМАЦЙНОЮ БЕЗПЕКОЮ, ІНТЕЛЕКТУАЛЬНИМ КАПІТАЛОМ ТА ІННОВАЦІЙНИМ РОЗВИТКОМ ГРОМАД
}

Анотація. Традиційне прагнення до знань та зростаюча роль інформаційного pecypcy. В той же час переважання споживацько-егоїстичного підходу у життєдіяльності та господарюванні визначили появу системної небезпеки існування людства, у тому числі інформаційного характеру. Творчість являє собою один із механізмів управління та спрямованого випромінювання енергії (цілеспрямованої дії), що зменшує втрати корисної потужності. Інтеграція еволюційних процесів людської спільноти, узгодженість людського буття із законами Світу сприяє формуванню стійкого підходу до пізнання, становлення життя нового якісного рівня як результат інформаційно-інтелектуального 
ноосферного переходу, а також результат розуміння необхідності відновлення витрачених ресурсів і стійку позицію формування духовності, етики та моралі як механізмам життя за законами Природи у відповідності до власного призначення. Перехід до нового світогляду обумовлений розумінням генетичної єдності Світу та розвитку соціуму на основі гуманістичного мислення. Фактично мова йде про керований комплекс еволюційних перетворень, що охоплює всі сфери життя людства. Базовими елементами системи інформаційно-інноваційного розвитку територіальної громади $\epsilon$ системно-синергетичні впливи як на фізичному, творчому, міжособистісному, соціальному рівнях, з позиції реалізації принципів реалізації найвищого потенціалу особистості як інтегрального комплексу можливостей особистості, а також включаючи універсальний (космічний) рівень. Холістичний (цілісний) підхід до принципово-логічної моделі локального соціуму (територіальної громади) дозволяє забезпечити становлення взаємозв'язаних елементів, кожен 3 яких $\epsilon$ результатом енерго-інформаційного впливу зовнішнього та внутрішнього середовища у їх еволюції. У вказаних умовах роль інформації стає визначальною. При цьому, питання інформаційної безпеки, достатності, відповідності, доступності та достатності інформаційних ресурсів, актуальність інформаційно-роз'яснювальної роботи, публічного управління визначає ефективність прийнятих рішень на всіх рівнях.

Ключові слова: державне управління, інтелектуальний капітал, інформаційні технології, комунікація, місцеве самоврядування, психологія управління, публічне управління, регіональний розвиток.

Voytenko Arhyp Borysovych PhD in Public Administration, Honored Lawyer of Ukraine, Professor of the Department of Economic Theory, Intellectual Property And Public Administration, Polissia National University, Staryi Blvd, 7, Zhytomyr, 10008, tel.: (067) 440-03-49, e-mail: public.znau@gmail.com, https://orcid.org/0000-00018661-2101

Khodakovsky Yevgeniy Ivanovych Doctor of Economic Sciences, Professor, Honored Science and Technology of Ukraine, Professor of the Department of Economic Theory, Intellectual Property And Public Administration, Polissia National University, Staryi Blvd, 7, Zhytomyr, 10008, tel.: (067) 440-03-49, e-mail: public.znau@gmail.com, https://orcid.org/0000-0001-8661-2101

Buluy Oleksiy Grigorovych $\mathrm{PhD}$ in Economics, Associate Professor of the Department of Innovative Entrepreneurship And Investment Activities, Polissia National University, Staryi Blvd, 7, Zhytomyr, 10008, tel.: (097) 219-10-83, e-mail: obuluy@ukr.net, https://orcid.org/0000-0003-3368-4835 
Plotnikova Mariia Fedorivna $\mathrm{PhD}$ in Economics, Associate Professor of the Department of Innovative Entrepreneurship And Investment Activities, Polissia National University, Staryi Blvd, 7, Zhytomyr, 10008, tel.: (067) 440-03-49, e-mail: mfplotnikova@gmail.com, https://orcid.org/0000-0003-2852-3009

\title{
PSYCHOLOGICAL FOUNDATIONS OF INFORMATION SECURITY MANAGEMENT, INNOVATIVE AND INTELLECTUAL CAPITAL OF COMMUNITY DEVELOPMENT
}

\begin{abstract}
The traditional desire for knowledge and the growing role of the information resource. At the same time, the predominance of the consumer-selfish approach in life and management determined the emergence of a systemic danger to human existence, including informational. Creativity is one of the mechanisms of control and directed radiation of energy (targeted action), which reduces the loss of useful power. The integration of the evolutionary processes of the human community, the consistency of human existence with the laws of the World contribute to the formation of a stable approach to knowledge. The formation of a new quality of life is the result of information-intellectual noosphere transition and an understanding of the need to restore spent resources. What is important is a stable position of the formation of spirituality, ethics, and morality as a mechanism of life according to the laws of Nature by its purpose. The transition to a new worldview is due to an understanding of the genetic unity of the world and the development of a society based on humanistic thinking. In fact, it is a controlled complex of evolutionary transformations, covering all spheres of human life. The basic elements of the system of information and innovation development of the territorial community are system-synergetic influences on the physical, creative, interpersonal, social levels. They also include the implementation of the principles of realization of the highest potential of the individual as an integral set of capabilities of the individual and include the universal (space) level. A holistic (holistic) approach to the principled-logical model of the local society (territorial community) allows ensuring the formation of interconnected elements, each of which is the result of the energy-informational influence of the external and internal environment in their evolution. Under these conditions, the role of information becomes decisive. At the same time, the issues of information security, sufficiency, adequacy, availability, and sufficiency of information resources, the relevance of outreach, public administration determine the effectiveness of decisions at all levels. Given the above, the formation of the information environment of the conditions of observance of higher spiritual laws (ethics and morality, universal values) is realized through various mechanisms. Through the mechanisms of the micro and macro social environment. At the physical level through ensuring the harmonious interaction of Man and Nature. It is important to take
\end{abstract}


into account biorhythms, including the Earth, the Sun, the planets. Food and other food systems are a condition for the harmonious development of society and its components and a mandatory part of public administration. The latter determine the level and quality of life, the status of individuals and their groups in society, the pace of systemic change through motivational and value components, system of life priorities, behavioral orientation, conditions, and individual lifestyle, mental state, knowledge system and cognitive component.

Keywords: public administration, intellectual capital, information technologies, communication, Local Self-Government, Management Psychology, Public Administration, Regional Development

Постановка проблеми. Науково-технічний прогрес вніс суттєві корективи у питаннях формування механізмів управління свідомістю. Наразі ключову позицію у прийнятті рішень на всіх рівнях відіграють інформація та знання. Функціонування інтернет-технологій запропонувало якісно нові можливості отримання та використання інформації. Тенденція до інформатизації має всеохоплюючий глобальний характер. Включеність національних та локальних систем управління як на державному, так i на регіональному рівні, загальна діджиталізації суспільства наразі багатьма учасниками суспільних відносин розглядаються як визначальний базис і формат отримання знань та інформації. Суспільство сприймає інформацію як ресурс, що споживається, формуючи середовище комп'ютерних користувачів. У такому форматі інформація стає основоположним механізмом управління свідомістю. У цьому ключі інформаційна безпека набуває статусу пріоритетного напряму у функціонуванні та поширенні інформаційних технологій. Зважаючи на те, що недотримання інформаційної безпеки спричиняє більше шкоди, ніж користі, особливої уваги потребує вивчення питань маніпулювання суспільною свідомістю та посиленого зростання економічної нерівності.

Аналіз останніх досліджень і публікацій. Яскравим прикладом ілюстрації інноваційно-інформаційних технологій в управлінні життєдіяльністю є розвиток smart-технологій, зокрема таких як smart-city, smart-community, smart-home, smartoffice тощо [1-2], що не може не спричиняти соціально-психологічний вплив на соціум. Соціальна специфіка розвитку «розумної інфраструктури», «розумної економіки i політики», «розумних технологій», «розумної стійкості» та «розумного здоров’я» ілюструю міждисциплінарний підхід до пошуку прийняття управлінських рішень у широкому спектрі сфер людського буття. Саме психологічний пріоритет управління інформацією, здатність до оперативної іiі оцінки, прогнозування та планування на всіх рівнях, у тому числі державного управління та місцевого самоврядування визначає пріоритет інтелектуальної 
складової управлінських рішень поряд 3 оптимізацією (або мінімізацією) необхідних витрат, наприклад на спожиті ресурси, зокрема такі як енергія, вода, продовольство, відходи, тепло, забруднення повітря тощо. 3 іншої точки зору саме інформаційні технології виявилися такими, що зумовили реалізацію моделі стійкості та ефективності підприємств на період пандемії [3], коли досягнення лідерських позицій, конкуренція на ринку робочої сили та адаптивна культура, прийняття більш обгрунтованих та децентралізованих рішень забезпечується за рахунок використання Інтернету та інтегрованих 3 ним комунікаційних технології, зокрема соціальних мереж, онлайн-комунікаційних платформ, забезпечуючи довіру та побудову зв'язків із співробітниками, зацікавленими сторонами та клієнтами під час і після кризи. Ще одним напрямом сучасного розвитку прямого включення громадян у інформаційно-комунікаційний процес, обумовлене саме потребою забезпечити децентралізацію та відповідний рівень довіри є використання блокчейн-технологій [4]. Іншими словами, зміна етичного, інформаційно-культурного середовища спричиняє додаткове навантаження на суб'єкти суспільних відносин, що має як позитивні, так і негативні наслідки. Розуміння цієї ситуації та адекватна реакція спроможні формувати підгрунтя для гармонійного розвитку людства у нових умовах.

Мета статті - виявлення якісних критеріїв, механізмів роботи та обгрунтування засад формування інформаційної безпеки в умовах становлення інтелектуального капіталу та забезпечення інноваційного розвитку територіальних громад.

Виклад основного матеріалу. Наразі інформаційні технології нарощують потенціал свого прояву у соціумі. Певно, жодна сфера людського буття не $\epsilon$ такою, що б не включала вплив та впровадження процесів інформатизації та активного прояву інформаційних технологій та їх впливу на розвиток суспільства. Саме завдяки інформатизації сучасна молодь посилює свою самоідентифікацію, розуміє власну здатність представити індивідуальність. Водночас важливість розуміння формування себе таким, яким індивід $\epsilon$, здатність раціонально ставитися до своїх недоліків, активно усуваючи їх актуалізує формування природодоцільних підходів до формату, подання та механізмів функціонування інформації у соціумі.

Інформацій наразі набула статусу творення чи руйнування, спричиняючи вплив у визначеній системі координат на основі сформованого понятійного апарату. Останній чітко позначає полюси (добро - зло, творчість - руйнування), а також механізми трансформації одного у інше. Інформаційні технології дозволяють легко створювати субкультури, формувати власні системи координат. Психологічно сформувалося так, що найчастіше такі механізми мають пізнавально-розважальний характер, а наслідок впливу визначається ступенем 
заглиблення у певну інформаційну систему, іiі відособленням індивідом. Кожна субкультура формує власний потенціал творення та руйнування як щодо своїх членів, так і щодо інших спільнот людей. Кількість потенціалів та цілі субкультури формуються ऑiі творцями, але не завжди $\epsilon$ очевидними іï послідовникам. Пізнавально-розважальний характер подання інформації привертає увагу особистостей, які стають користувачами субкультури. Визначений час контакту 3 конкретним інформаційним полем вписує користувачів до цієї системи координат, являючись базою для світосприйняття та світорозуміння. Недотримання золотих пропорцій процесу вибудовування інформаційного поля призводить до руйнації суспільних відносин (заглиблення у різні інформаційні середовища можуть стати причиною того, що люди перестають розуміти один одного).

Наразі найбільш інформаційно безпечними залишаються природовідповідні технології управління та методи взаємодії людини 3 інформацією. Вони забезпечують дотримання генетично детермінованого способу приймання, обробки, відтворення та архівування інформації у системі «людина». Так звані біологічні коди, відкриті у кінці ХХ ст. фізиками, фізіологами, нейрофізіологами, медиками, психологами, зокрема такими як Борис Астаф’єв [7], Масару Емото [8]. Опосередковано інформаційний вплив на соціум можна оцінити за результатами структурування води під впливом інформації, що ілюструє ступінь гармонізації інформації з їі приймачем та користувачем, дає можливість оцінити шкоду, яка може бути нанесена організмові людини. Одночасно питання інформаційної безпеки визначають межі цензури: від шкідливої інформації має бути обмеження як і від будь-якого іншого шкідливого чинника, тоді як корисна інформація визначає ефективність розвитку соціуму. Інформація останнього типу може формувати середовище творчості в силу того, що функціонує у гармонії із біологічними кодами, інша, навпаки, - несе у собі потенціал руйнації, формуючи зону інформаційного конфлікту у середині особистості. Лише робота 3 інформацією та управління соціумом на основі золотих пропорцій (золоті пропорції передбачають використання 65\% відомої інформації, 30\% нової позитивної інформації, 5\% негативної або нової чи невідомої інформації) забезпечує безпеку, комфорт та розвиток індивідів і їх груп [10]. Так, традиційно людству відомі культурні інформаційні коди, які забезпечують самоідентифікацію людини та нації. Існують також гендерні коди розвитку інформації, що може проявлятися в особливостях сприйняття та самовираження. Наявні коди Роду, родини покликані зберігати спадковість поколінь (батьки та діти живуть у єдиному інформаційному просторі, що забезпечує комфортний спільний розвиток).

При цьому критеріями ефективності функціонування $€$ соціально- 
психологічні та інноваційно-інтелектуальні характеристики соціуму та інших елементів системи «територіальна громада»: рівень розвитку самодіяльності; частка населення, яке займається особистісним розвитком на професійному рівні (фізична культура, спорт, освіта, наука, мистецтво тощо); рівень культури, освіти і виховання, зокрема серед дітей, молоді; рівень свідомості населення; ставлення населення до природи (навколишнього простору) - творче, споживацьке, руйнуюче; чи $є$ взаємодія людини 3 простором згармонізованою; частка населення, яка $є$ прихильниками гармонізації відносин 3 Природою; частка населення, яка прагне i робить конкретні кроки, щоб жити у більш якісних умовах; частки тих, хто у якості пріоритетного бачить духовний розвиток; частка населення громади, які обрали духовний розвиток своїм способом життя; розвиток громади відповідно до Божественних зразків (природовідповідність); чи сприяють відносини у громаді якісному рівню життя населення, його оздоровленню, духовному розвитку особистостей.

Наслідком певної інформаційної політики стала популяризація глобалістичних процесів та міського способу життя. Загальне погіршення якості життя населення, у тому числі за рахунок процесів урбанізації, інтенсифікації та індустріалізації суспільного середовища та, як наслідок, зниження родючості грунтів, забруднення водних, повітряних та земельних ресурсів токсичними відходами життєдіяльності людей водночас супроводжується зниженням рівня зайнятості та самозайнятості, що додатково створює соціальне напруження. Одним з варіантів поліпшення наявної ситуації є розробка іншого стійкого образу (гештальту) як моделі існування людства, зокрема через реалізацію ідеї «Родова садиба». Практична їі реалізація на теренах України (без жодного стимулювання 3 боку держави у період з 2000 по 2020 р. на різній стадії становлення відновлено 100 населених пунктів на сільських територіях) проілюструвала багатофункціональний характер позитивних змін щодо вирішення житлової, демографічної проблем, а також мало позитивні наслідки щодо відновлення локальних економік, реалізації політики продовольчої та екологічної безпеки. Заселення 1200 населених пунктів з числа тих, що зникли з мапи України за часів незалежності та тих, у яких жилими числиться від 1 до 10 будинків сприятиме підвищенню рівня зайнятості в межах країни на 100 тис. осіб, створить прецедент безповоротних вкладень у розвиток територій (однією Родовою садибою за 10 років) на суму понад 300 тис. грн., щорічно поповнюватиме бюджети ОТГ, каналізуватиме грошовий потік у формі податків та сприятиме виробництву екологічно чистої продукції [9]. Основними беніфіціарами таких змін є ОТГ, держава та населення, а також мешканці міст та зарубіжні громадяни у межах практики зеленого сільського туризму. При цьому треба розуміти, що бути у авангарді модернізації суспільних процесів є більш вигідно навіть економічно, 
ніж реагувати на наявні зміни постфактум. Наприклад такими є результати невдалих бізнес-стратегій всесвітньовідомих брендів, що позначилися репутаційними втратами внаслідок неадекватного реагування на оцінки суспільних очікувань (прикладами таких ситуацій $є$ мільйонні втрати Unitted Airlines через грубе поводження із пасажирами, наслідки розпізнавання облич у Facebook). Натомість протилежна ситуація 3 Nike щодо випуску рекламного ролика із участю футболіста та громадського активіста Коліна Каперника лише додала популярності бренду. Практика доводить позитивні наслідки ефективності функціонування гендерно змішаних команд, учасників із різних національних, вікових та інших суспільних категорій (креативність та прибутковість рішень таких команд є на 11\% вищою, порівняно із традиційними групами). Як окремі індивіди, так і всесвітньовідомі бренди підтримують соціальні проєкти, наприклад, боротьби за гендерну рівність та проти расизму. Такими наразі $\epsilon$ чисельні громадські об'єднання, які інформаційно та організаційно закликають та сприяють вирішенню суспільно важливих питань, тоді як їх ігнорування вже зараз визначає репутаційні, бізнесові (економічні) втрати, юридичні (зокрема, адміністративні) санкції та посилення недовіри як 3 боку інвесторів, так i суспільства. Наразі як окремі індивіди, так і цілі групи схиляються до зміни свого світогляду на гармонізацію відносин із природою, зокрема, близько половини міського населення бажає жити ближче до природи. Тому більш гостро постає питання інформаційної роботи щодо підготовки соціальної реклами у 3МI, проведення заходів (круглих столів, громадських слухань, фестивалів, свят, івентів тощо) щодо перспективного напряму розвитку країни та планети у цілому.

Зважаючи на те, що структура інтелектуального капіталу включає людський, ринковий, структурний та споживчий капітал, він покликаний сприяти людині у

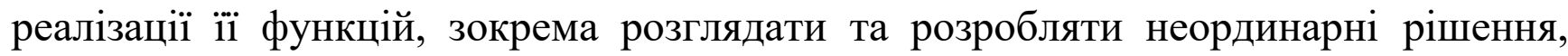
висувати креативні ідеї, є джерелом ініціації та впровадження інституційних змін, формування інноваційних моделей соціально-економічного розвитку та, як наслідок, моделі поведінки, продуктів, технологій, системи та наслідків освітнього та управлінського процесу. Орієнтована на забезпечення стійкого розвитку, набуття світоглядних та інших переваг соціуму, їх стійкості до негативних зовнішніх впливів як на локальному, так i національному рівні система інтелектуального капіталу покликана розвивати творчі здібності всіх стейкхолдерів територіальних громад. Іншими словами, розвиток інтуїції, формування навичок швидкого прийняття рішень, прийняття неординарних рішень, креативного мислення, примноження нематеріальних форм капіталу (зокрема, таких як брендинг та технологій ефективного використання ресурсів територій) виявляється наразі найактуальнішою складовою механізму розвитку. Успішність розвитку територіальної громади на засадах інформаційної безпеки 
лежить у площині інноваційного розвитку регіону на засадах синергетичної взаємодії інтелектуального капіталу індивідів, підприємств та організацій, а також регіональних та державних органів влади (рис. 1).

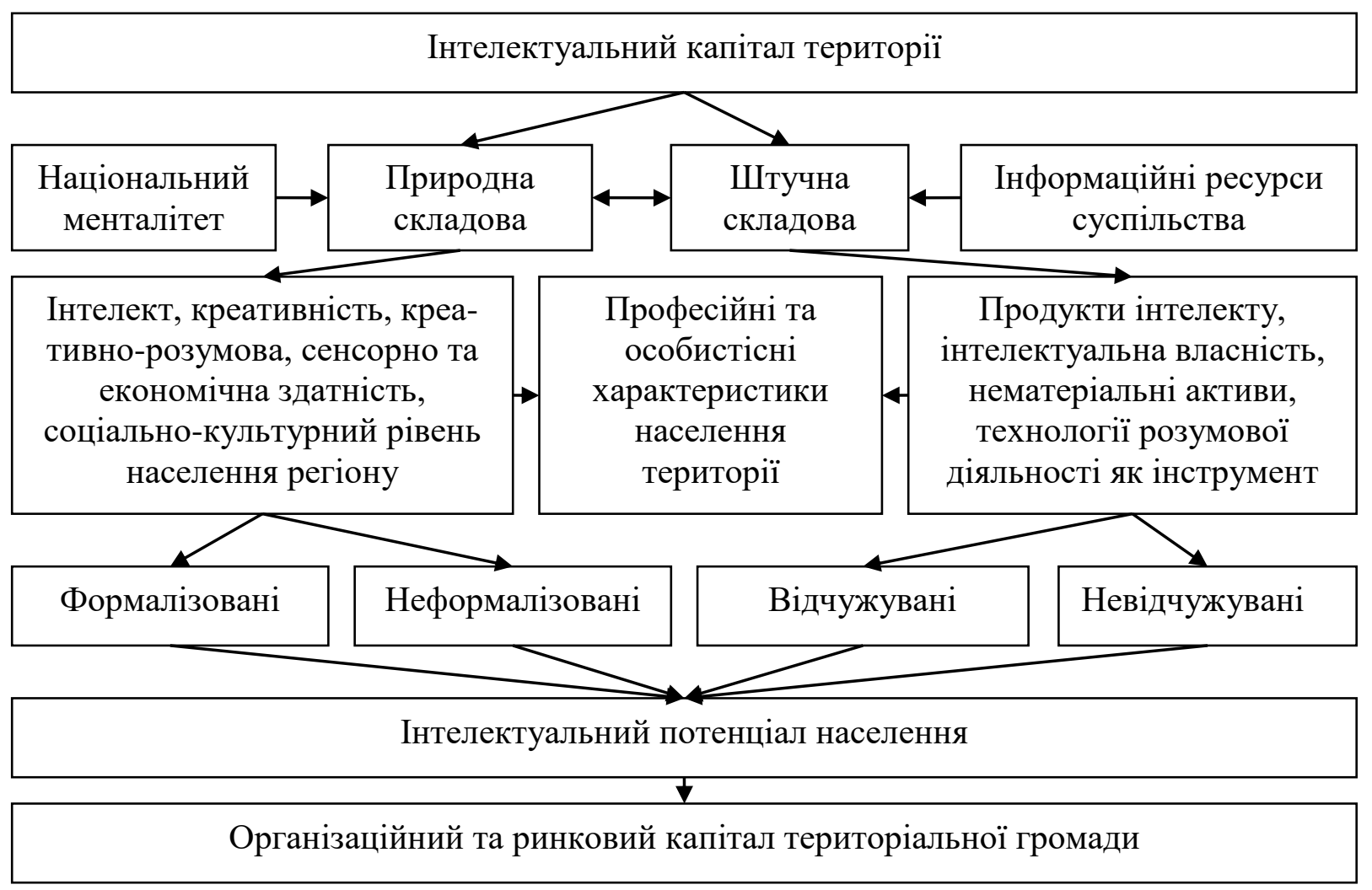

Рис. 1. Структура інтелектуального капіталу території

Сформульовані концептуальні положення ілюструють загальні підходи до оцінки інтелектуального капіталу території як соціально-економічної системи та об'єктивної умови іiі інноваційного розвитку (як результат розуміння того, що формування інтелекту $\epsilon$ головною виробничою силою, базою становлення інноваційної економіки, а інформація - ключовий ресурс, продукований людиною). Враховуючи зазначене, ключовою потребою людини $є$ творчість, праця та розвиток, що забезпечують стійкі переваги на основі інновацій. Розкриті у працях В. І. Вернадського та інших дослідників [6-7, 10] та засновані на законах Прогреса і Регреса характерні риси майбутньої цивілізації, дозволили зробити висновок про їх діяльність: 1) сучасна життєдіяльність Біосфери заснована на Паразитуванні ланцюгів живлення, де сильний з’їдає слабкого, що знайшло своє відображення і у соціумі; 2) управління Біосферою закладене на рівні інстинктів у кожному виді живих організмів і реалізується через генофонд, тому тварина не може вийти за межі своїх інстинктів; 3) життєдіяльність людини має свободу волі i є заснованою на Свідомості, а не лише на природних інстинктах і набуває свого розвитку за рахунок колективного спілкування, почуття співчуття (спільного 
переживання), інтелектуальної згуртованості, ритуалів етноса, національній державності, екологічній культурі; 4) у взаємодії з навколишнім середовищем людина створює штучне середовище існування (ноосферу: житло, поселення, міста, держави, галузі виробництва, науку, культуру); 5) 3 позиції ланцюгів живлення людина $є$ консументом і паразитизм закріпився у іiі відомості, що обумовило паразитичний розвиток цивілізації (рабство, рабовласницький, феодально-кріпосний, капіталістичний устрої, соціальний тоталітаризм, масонство, мафію та олігархію у межах демократичного устрою, війни, прагнення до влади та світового володарювання, ядерної зброї тощо); 6) управління ноосферою базується на родових генофондах, які накопичують інтелектуальну та духовну інформацію кожного роду, створюють Суспільну та Національну Свідомість за участю державної влади (на противагу сучасному психотропному бомбуванню, психотропній зміні свідомості, робото керованих чипам, мутантам i кіборгам для управління людиною через страх та неусвідомлюване); 7) сучасна цивілізація підійшла до точки біфуркації Всесвітнього Закону Прогресу та Регресу, тому перспективним напрямом для забезпечення розвитку людства $\epsilon$ перехід на стадію Мудрості через Екологічну культуру людини у ноосфері; 8) крім матеріальної ноосфери існує ноосфера віртуальна (думка, мова, ЕГО, творчість, свідомість, підсвідомість, розум), які спроможні дозволити людині стати автотрофною, пройти стадії пізнання, усвідомлення та осяяння та досягти стадії Мудрості, що за рахунок екологічної культури уможливить зміну свідомості від споживацької на ноосферну (рис. 2), які, у свою чергу, розкриваються 3 позиції таких рівнів сприйняття: 1) рівень егоцентричної обмеженості; 2) рівень родинних цінностей; 3) рівень національних цінностей; 4) рівень загальнолюдських цінностей; 5) рівень духовного (космічного) усвідомлення. Подолання наявних бар'єрів наразі відбувається на основі формування єдиного світогляду через систему нових знань, інформаційної роботи, творчість. Інтеграція найчастіше забезпечується на рівні та за допомогою фізико-хімічних процесів, енергетичної взаємодії, інформаційної синхронізації (донесення інформації, через системи обробки інформації та управління процесами), розуміння власного структурно-функціонального призначення, через гештальт (коли голографічний формат думки створює подальші передумови розвитку), дух. 


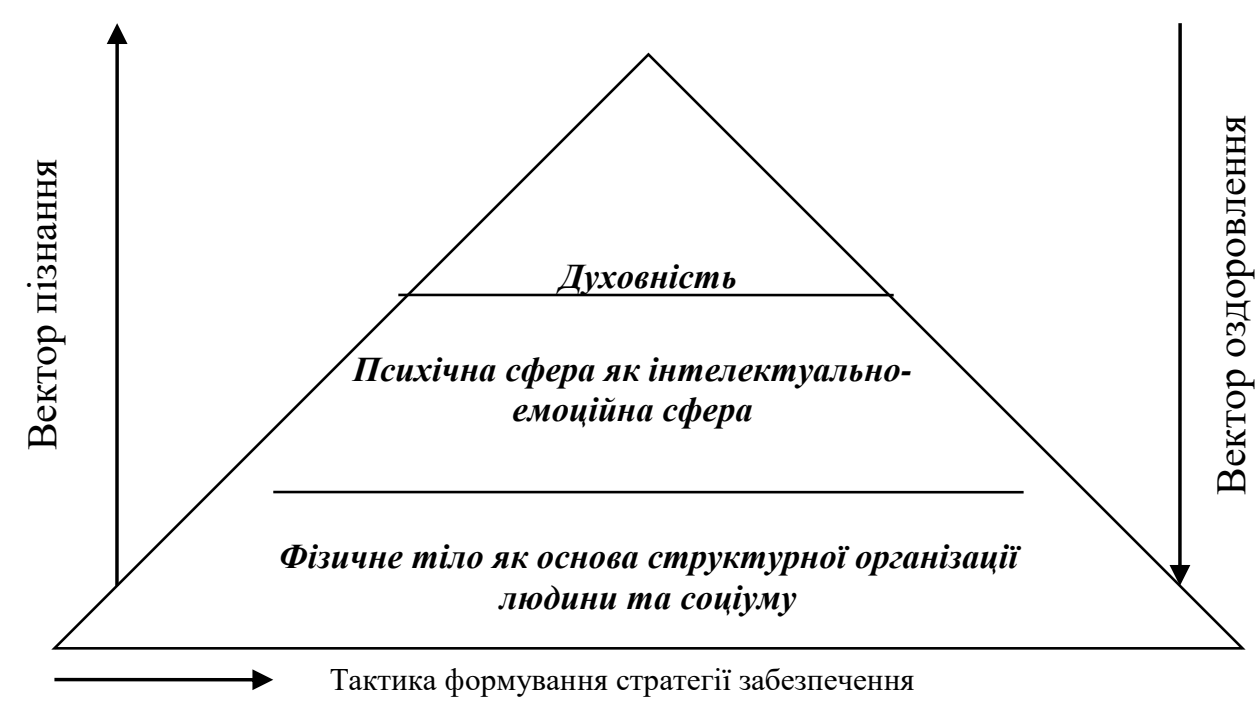

Pис. 2. Ноосферні підходи до пізнання та оздоровлення

Зростаючі темпи урбанізації та відсторонення людини від природного середовища особливо гостро визначає пошук гармонізації та відновлення людської особистості та простору, що іiї оточує. У цьому ключі впровадження ноосферних підходів у життєдіяльність та господарювання посилює синтез природних образів, їх глибинне розуміння та необхідність збереження як запоруки існування соціуму, створення інформаційного базису його процвітання. Ноосферний світогляд $\epsilon$ форматом уникнення катастрофи i механізмом формування моделі гармонічної людської спільноти, головування Розуму над стихійністю. Ноосферна концепція розвитку людства передбачає практичну реалізацію пріоритетної концепції сталого розвитку як (рис. 3).

Соціуму як складовій самоорганізованої термодинамічної нерівнозваженої планетарної системи властива складна організованість, яка підвищується від переходу від матеріальної системи до духовної. У відповідності із законом причини та наслідку людина може керувати власною долею («що посієш, те й пожинати будеш»). Іншими словами, законами життя соціуму мають стати такі: 1) відноситися до всього з любов'ю (тоді, за законом зворотного зв'язку, все теж буде відноситися 3 любов'ю); 2) не допускати негативних думок (контроль за власним ЕГО формує емоції та настрій, що дозволяє позбавитися від стресу та проблем); 3) доброта та сердечність як запорука здоров'я, довголіття та щастя (зокрема, сердечна доброта дає енергію імунній системі та сприяє стійкості гомеостазу, кінетика хімічних реакцій забезпечує рентабельне проходження обміну речовин та омолодження клітин, нервова система сповнена позитивними емоціями радісно сприймає життя). 
Основні положення концепції сталого розвитку соціуму на засадах ноосферизму

Пріоритет духовних цінностей та недопущення надмірного матеріального виробництва

Перехід до раціонального інформаційного суспільства та бімодальних екологічно чистих технологій

Подальший розвиток соціуму у відповідності до ресурсів біосфери та пріоритетного характеру формування ноосфери Землі

Орієнтація національних економік на ресурсозберігаючі галузі, демілітаризацію соціуму, прискорений розвиток науки, культури та освіти

Розробка довгострокових прогнозів та програм екологічного розвитку світу, глобальний моніторинг екологічної безпеки

Фундаментальне вивчення енергоінформаційного простору ноосфери з метою виявлення важливих космічних законів, геологічних циклів та ритмів, які визначають розвиток соціуму

Формування «нового планетарного порядка» цілеспрямованої діяльності, колективного інтелекта планети з урахуванням загальної економічної, екологічної ситуації та ноосферогенеза

\section{Puc. 3. Основні положення концепиії сталого розвитку соиіуму на засадах ноосферизму}

Тому напрямом розвитку та інформаційної безпеки соціуму стає ноосферна траєкторія: знак - символ - значення - сенс - усвідомлення - практика. Усвідомлення та прийняття сучасною людиною необхідності вектора духовносвітоглядних новацій сьогодення на чолі із одухотвореним розумом (під одухотвореним розумом розуміємо органічну єдність інтелектуального розуму, високу душу i дух, які спрямовують людину на досягнення найвищих потенційних можливостей та виконання життєвого призначення на Землі).

Висновки. Інтелектуальний капітал як результат системної взаємодії органів влади, суспільства та інших суб'єктів на території зазнає значного впливу інформаційного середовища, безпека якого напряму залежить від потенціалу (умов формування: науково-дослідної, інноваційно-підприємницької, культурноосвітньої складових), а також здатності усіх стейкхолдерів забезпечити власний та сукупний гармонійний інноваційний розвиток. Синергетичним ефектом функціонування вказаних елементів середовища $є$ інтелектуальні продукти, що воно породжує, а також виробничо-галузеві, науково-технічні та духовно-етичні кластери формування інноваційної політики регіону як сукупний продукт взаємодії органів влади та суспільства.

Людина являє собою складну фізичну та інформаційно-енергетичну систему, 
яка функціонує у єдності із оточуючим середовищем та ефективно само реалізується через Духовність, прямий контакт із Душею, Розумом. У процесі погіршення економічної, соціально-політичної та екологічної ситуації у світі людству стає зрозумілим хибність стратегії односторонньої маніпуляції та контролю над матеріальним світом та нехтування системного підходу до пізнання Законів Всесвіту.

\section{Jimepamypa:}

1. Stübinger J., Schneider L. Understanding smart city - a data-driven literature review. Sustainability (Switzerland). 2020. Vol. 12(20), 8460, P. 1-23.

2. Chang I.-C.C., Jou S.-C., Chung M.-K. Provincialising smart urbanism in Taipei: The smart city as a strategy for urban regime transition. Urban Studies. 2021. Vol. 58(3), P. 559-580.

3. Obrenovic B., Du J., Godinic D., Khan M.A.S., Jakhongirov I. Sustaining enterprise operations and productivity during the COVID-19 pandemic: "Enterprise effectiveness and sustainability model". Sustainability(Switzerland). 2020. Vol. 12(15), P. 59-81.

4. Oliveira T.A., Oliver M., Ramalhinho H. Challenges for connecting citizens and smart cities: ICT, e-governance and blockchain. Sustainability (Switzerland). 2020. Vol. 12(7), Is. 2926.

5. Якобчук В. П., Присяжнюк О. Ф., Плотнікова М. Ф., Булуй О. Г. Екологічні поселення як механізм управління багатофункціональним розвитком сільських територій. Стратегія інклюзивного сільського розвитку на базі громад: проекти, реалії та європейські перспективи для України: монографія / за ред. проф. Т. О. Зінчук. Київ: «Центр учбової літератури», 2019. 316-334.

6. Якобчук В. П., Плотнікова М. Ф. Інноваційні механізми управління розвитком територіальних громад. Економічний та управлінський потенціал соціальної економіки: монографія / за заг. ред. З. І. Галушки. Чернівці: Чернівецький нац. ун-т ім. Ю. Федьковича, 2020. C. 223-241.

7. Астафьев Б. А. Теория творения и генетического единства мира - основа мировоззрения будущего человечества. Мир (Модернизация. Инновации. Развитие). М.: ФГУП ВИНИТИ, 2013. С. 52-56.

8. Эмото М. Послания воды: Тайные коды кристаллов льда. М.: София, 2005. 96 с.

9. Плотнікова М. Ф., Присяжнюк О. Ф. Історико-культурні та сучасні тенденції розвитку сільського туризму в родових поселеннях. Науковий вісник Полтавського університету економіки і торгівлі. 2018. № 4 (89). С. 112-117.

10. Ульянова М. В. Технология золотого миллиарда: как сделать «потерянное поколение». Ноосферное образование как антикризисная социальная технология. М.: ООО «Традиция», $2017.40 \mathrm{c}$.

\section{References:}

1. Stübinger, J., Schneider, L. (2020) Understanding smart city - a data-driven literature review. Sustainability (Switzerland), 12(20), 8460, 1-23.

2. Chang, I.-C.C., Jou, S.-C., Chung, M.-K. (2021) Provincialising smart urbanism in Taipei: The smart city as a strategy for urban regime transition. Urban Studies, 58(3), 559-580.

3. Obrenovic, B., Du, J., Godinic, D., Khan, M.A.S., Jakhongirov, I. (2020) Sustaining enterprise operations and productivity during the COVID-19 pandemic: "Enterprise effectiveness and 
sustainability model". Sustainability(Switzerland), 12(15), 59-81.

4. Oliveira, T.A., Oliver, M., Ramalhinho, H. (2020) Challenges for connecting citizens and smart cities: ICT, e-governance and blockchain. Sustainability (Switzerland), 12(7), 2926.

5. Yakobchuk. V. P., Prysyazhnyuk, O. F., Plotnikova. M. F., Buluy, O. G. (2019) Ekolohichni poselennia yak mekhanizm upravlinnia bahatofunktsionalnym rozvytkom silskykh terytorii [Ecological settlements as a mechanism of management of multifunctional development of rural territories]. Strategy of inclusive rural development on the basis of communities: projects, realities and European perspectives for Ukraine: monograph / prof. TO Zinchuk (ed.). Kyiv: Center for Educational Literature, (pp. 316-334) [in Ukrainian].

6. Yakobchuk, V. P., Plotnikova, M. F. (2020) Innovatsiini mekhanizmy upravlinnia rozvytkom terytorialnykh hromad [Innovative mechanisms for managing the development of territorial communities]. Economic and managerial potential of social economy: monograph / Z. I. Halushky (general. ed.). Chernivtsi: Chernivtsi National University Univ. Yu. Fedkovich, (pp. 223-241) [in Ukrainian].

7. Astafev, B. A. (2013) Teoryia tvorenyia y henetycheskoho edynstva myra - osnova myrovozzrenyia budushcheho chelovechestva. Myr (Modernyzatsyia. Ynnovatsyy. Razvytye) [The theory of creation and genetic unity of the world - the basis of the worldview of future humanity. Peace (Modernization. Innovation. Development)]. Moscow: FGUP VINITI, (pp. 52-56) [in Russian].]. Moscow: FHUP VYNYTY,. S. 52-56 [in Russian].

8. Emoto, M. (2005) Poslanyia vodы: Tainыe kodы krystallov lda [Messages of water: Secret codes of ice crystals]. Moscow: Sofyia.

9. Plotnikova, M. F., Prysiazhniuk, O. F. (2018) Istoryko-kulturni ta suchasni tendentsii rozvytku silskoho turyzmu v rodovykh poselenniakh [Historical, cultural and modern trends in rural tourism in tribal settlements]. Scientific Bulletin of Poltava University of Economics and Trade, 4(89), (pp. 112117) [in Ukrainian].

10. Ulianova, M. V. (2017) Tekhnolohyia zolotoho myllyarda: kak sdelat «poteriannoe pokolenye». Noosfernoe obrazovanye kak antykryzysnaia sotsyalnaia tekhnolohyia [Technology of the golden billion: how to make a "lost generation". Noosphere education as an anti-crisis social technology]. Moscow: LLC "Tradition". 